\title{
FRAGMENTO SOBRE MÚSICA E LINGUAGEM ${ }^{1}$ Theodor Adorno
}

A música assemelha-se à linguagem. Expressões como idioma musical e entonação musical não são nenhuma metáfora. Contudo, música não é linguagem. Sua similitude com a linguagem indica o caminho para o intrínseco, bem como para o vago. Quem toma a música ao pé da letra como linguagem é induzido ao erro.

A música assemelha-se com a linguagem na qualidade de sequência temporal de sons articulados, que são mais do que meros sons. Eles dizem algo, frequentemente algo humano. Dizem tão mais enfaticamente, quanto mais à maneira elevada estiver a música. A sequência de sons converteu-se em lógica: existe certo e errado. Porém, aquilo que foi dito não pode se depreender da música. Ela não compõe nenhum sistema de signos.

A similitude com a linguagem desce do todo - a conexão organizada de sons importantes - até chegar ao som singular - a nota como o limiar da mera existência, o puro suporte da expressão. A música é análoga ao discurso não apenas como conexão organizada de sons, mas também porque há uma semelhança com a linguagem no modo de sua estrutura concreta. A doutrina musical tradicional da forma [Gestalt] instrui sobre oração, frase, período, pontuação; interrogação, exclamação, parênteses; orações subor-

1 Traduzido do alemão ["Fragment über Musik und Sprache". In: Musikalische Schriften I-III: Band 16. Digitale Bibliothek Band 97: Theodor W. Adorno: Gesammelte Schriften, S. 13007 (vgl. GS 16, S. 251 ff.)], cotejado com a tradução para o inglês ("Music and Language: a Fragment". In: ADORNO, Theodor. Quasi una Fantasia. Essays on Modern Music. Traduzido por Rodney Livingstone. Londres/Nova York: Verso, 1996) e para o espanhol ("Fragmento sobre música y lenguaje". In: ADORNO, Theodor. Escritos musicales I-III. Traduzido por Alfredo Brotons Muñoz e Antonio Gómez Schneekloth. Madri: Ediciones Akal, 2006). Tradução de Manoel Dourado Bastos, doutorando em História (Unesp-Assis), bolsista Fapesp. 
dinadas são encontradas por toda parte, vozes ascendem e descendem, e em todas elas o gestus da música é emprestado da voz que fala. Quando Beethoven indica que uma das bagatelas do op. $33^{2}$ seja executada "com consciente expressão falante", ele tão-somente explicita um momento onipresente da música ao refleti-lo.

Nesse particular, costuma-se tratar o diferenciado pelo fato de a música não conhecer conceitos. Porém, muitos elementos da música aproximam-se dos "conceitos primitivos" de que trata a teoria do conhecimento. A música utiliza sinais recorrentemente. Estes foram moldados pela tonalidade. Se, por um lado, não produz conceitos, por outro, ela produz vocábulos: primeiramente os acordes que reaparecem sempre com função idênti$\mathrm{ca}$, a seguir as ligações gastas como as progressões de cadências, muitas vezes os próprios floreios melódicos que parafraseiam a harmonia. Tais sinais universais sempre podiam adentrar em conexões particulares. Eles ofereciam espaço para as especificações musicais, assim como o conceito o faz para o singular e, igualmente à linguagem, foram simultaneamente redimidos de seu caráter abstrato em virtude do contexto. Só que a identidade desses conceitos musicais aloca-se em sua própria constituição e não em algo denotado por eles.

A invariância desses conceitos musicais sedimentou-se igualmente numa segunda natureza. Ela torna muito difícil para a consciência a separação da tonalidade. Porém, a nova música rebela-se contra a aparência em tal segunda natureza. As fórmulas coaguladas e suas funções, ela as elimina por serem mecânicas. De modo algum, entretanto, ela elimina a similitude com a linguagem, antes apenas da reificada, que abusa do elemento individual como uma ficha, um sinal desqualificado de significados subjetivos não menos petrificados. Musicalmente, subjetivismo e reificação também se correspondem mutuamente. Mas, esta correlação não define de uma vez por todas a semelhança da música com a linguagem em geral. Hoje, a relação entre música e linguagem tornou-se crítica.

A música, em relação à linguagem intencional, mostra-se de um tipo totalmente diferente. É nisto onde se situa seu aspecto teológico. O que ela diz é, como fenômeno, simultaneamente determinado e ocultado. Sua ideia é a forma [Gestalt] do nome divino. Ela é prece desmitificada, livre da magia influente [Einwirken]; é a tentativa humana, ainda como sempre frustrada, de nomear o Nome ele mesmo, e não de comunicar significados.

A música aponta para uma linguagem desprovida de intenção. Porém, ela não se separa definitivamente do intencional como reinos distintos.

2 "Sete bagatelas para piano, opus 33", N.T. 
Impera aí uma dialética: ela está disseminada de intenção por todas as partes, e certamente que não apenas desde o stile rappresentativo, que guiou a racionalização da música para dispor de sua similitude com a linguagem. Música sem qualquer intenção, a mera conexão fenomênica dos sons, pareceria um caleidoscópio acústico. Por outro lado, como intenção absoluta, ela cessaria de ser música, e se converteria falsamente em linguagem. Intenções lhe são essenciais, mas apenas de maneira intermitente. Ela remete à linguagem verdadeira como aquela em que o próprio conteúdo seria manifesto, porém ao preço da univocidade, que se encaminhou para a linguagem intencional. E como ela, a mais eloquente de todas as linguagens, devesse ser consolada sobre a maldição da ambiguidade - sua parte mítica -, as intenções a ela afluem. Ela reiteradamente indica que significa algo de maneira determinada. Apenas a intenção está sempre simultaneamente oculta. Não de maneira gratuita, precisamente Kafka concedeu espaço à música em textos memoráveis como nenhum escritor antes. Ele procedeu com os significados da linguagem falada, intencional, como se fossem os da música, como parábolas interrompidas, em extrema oposição com a linguagem "musical" de Swinburne ou Rilke, com seus efeitos musicais imitados e estranhos à abordagem musical. Ser musical significa incitar intenções relampejantes sem nelas se perder, mas sim as domando. Assim, a música constitui-se como estrutura.

Isso remete à interpretação. Música e linguagem pedem esta na mesma medida e de modo totalmente distinto. Interpretar a linguagem significa: entender a linguagem; interpretar a música: fazer música. A interpretação musical é a consumação, como síntese, que preserva a similitude com a linguagem ao mesmo tempo em que anula todas as semelhanças isoladas com esta. Eis porque a ideia de interpretação pertence à música mesma e não lhe é acidental. Tocar música corretamente, todavia, é antes de tudo dizer corretamente sua linguagem. Esta requer uma imitação de si própria, não sua decifração. Somente na práxis mimética, que decerto pode ser interiorizada silenciosamente na imaginação à maneira da leitura silenciosa, a música se abre; jamais em uma observação que a interprete independentemente de sua execução. Se se desejar um ato semelhante ao da música na linguagem intencional, este seria antes a transcrição de um texto do que sua compreensão em significados.

Em contraste com o caráter cognitivo da filosofia e das ciências, na arte os elementos reunidos para o conhecimento nunca se ligam ao juízo. É, contudo, a música de fato uma linguagem desprovida de juízo? Entre suas intenções, uma das mais insistentes parece o "isto é assim"; a confirmação judiciosa, mesmo sentenciosa, de algo todavia não manifestamente afirmado. Nos mais altos, decerto também os mais violentos, momentos da grande música, como no início da recapitulação no primeiro movimento da Nona 
Sinfonia, esta intenção se faz, por meio da mais pura força do contexto, inequivocamente eloquente. Ela ecoa parodiada em peças menores. A forma musical, a totalidade na qual uma coesão musical ganha seu caráter autêntico, dificilmente desiste da tentativa de dotar o meio desprovido de juízo do gestus do juízo. Às vezes isto resulta tão radical que o limiar da arte quase não resiste ao assalto da vontade de domínio lógico.

Assim sendo, a diferença entre música e linguagem não será encontrada em nenhuma de suas feições singulares, senão apenas no todo de seu contexto. Ou, ainda mais, em sua orientação, sua "tendência", a palavra pura e simplesmente empregada na ênfase extremada do telos da música. A linguagem intencional gostaria de afirmar de maneira mediada o absoluto, que lhe escapa em cada intenção específica, deixando cada uma atrás de si como finita. A música depara imediatamente com o absoluto, mas, no mesmo instante, ele se ofusca, do mesmo modo que a luz muito intensa cega os olhos, que assim não conseguem mais ver o totalmente visível.

A música termina por expor outra vez sua semelhança com a linguagem na medida em que, fracassada, é enviada à odisseia da mediação infinita, tal qual a linguagem intencional, rumo à impossível volta para casa. Sua mediação apenas difere daquela da linguagem intencional por desdobrar-se sob outra lei: não nos significados que se remetem mutuamente, mas sim na mortal absorção por um contexto do qual somente se salva o significado desprezado por ele em cada movimento singular. A música rompe suas intenções dispersas por sua própria força e admite reuni-las à configuração do Nome.

A fim de distinguir a música da mera sucessão de estímulos sensoriais, definiu-se um contexto de sentidos ou estrutural. Na medida em que na música nada permanece isolado e tudo se torna o que é apenas no contato físico com o próximo e no espiritual com o longínquo, na lembrança e na expectativa, é possível deixar passar estas definições. Porém, o contexto não é o dos sentidos, tal qual o instituído pelas linguagens intencionais. O todo se realiza contra as intenções, integrando-as por meio da negação de cada intenção singular, não-fixável. A música enquanto um todo acolhe as intenções, não ao diluí-las em uma intenção abstrata, maior, mas sim no instante em que esta é derrubada, ao se dispor à evocação da ausência de intenção. Assim, ela é quase o contrário de um contexto de sentidos, mesmo onde ela, em relação ao existente sensível, restitui tal contexto. Disto resulta a ela a tentação de subtrair-se, por seu próprio poder, de todos os sentidos: comportar-se como se fosse, de fato, imediatamente o Nome.

Heinrich Schenker partiu o nó górdio da antiga controvérsia e declarou-se contra as estéticas tanto da expressão quanto da forma. Em lugar destas, ele visou - de resto, assim como Schönberg, por ele vergonhosamente incompreendido - um conceito de conteúdo musical. A estética da 
expressão confunde as intenções singulares, ambiguamente fugidias, com o conteúdo, desprovido de intenção, do todo; a teoria de Wagner se apequena, porque ela apresenta o conteúdo da música de acordo com uma expressão infinitamente espalhada por todos os instantes musicais, ao passo que a afirmação do todo é qualitativamente diferente da significação singular. A consequente estética da expressão termina na sedução arbitrária de imputar a compreensão efêmera e fortuita à objetividade da coisa-em-si. Porém, a tese contrária, aquela das formas [Formen] movidas sonoramente, desemboca no estímulo vazio ou na mera existência do sonoro, que prescinde daquela referência da figura [Gestalt] estética, que o próprio sonoro não é e somente por meio da qual se torna figura [Gestalt] estética. Sua simples e, por causa disso, sempre popular crítica à linguagem intencional a sacrifica ao preço do artístico. Assim como a música não se esgota em intenções, tampouco, de maneira inversa, não se encontra uma música em que o elemento expressivo não apareça: em música, mesmo a falta de expressividade torna-se expressão. "Sonoro" e "movido" são em música quase o mesmo, e o conceito "forma" [Form] nada esclarece do que foi ocultado, senão meramente desloca a questão para antes do que se apresenta no contexto sonoramente movido, algo que é mais do que apenas forma. Forma [Form] é somente aquela do que foi formado [Geformtem]. É a necessidade específi$\mathrm{ca}$, a lógica imanente que àquela consumação escapa: ele [o conceito de "forma"] se tornará um mero jogo, em que literalmente tudo poderia ser outra coisa. O conteúdo musical, porém, é, na verdade, a plenitude de tudo o que sucumbe à gramática e sintaxe musicais. Todo fenômeno musical aponta para além de si pelo vigor daquilo que relembra, de que se remove e pelo que desperta expectativas. A essência de tal transcendência da singularidade musical é o "conteúdo": o que acontece na música. Se, porém, a estrutura musical ou a forma [Form] devem ser mais do que esquemas didáticos, então elas não abarcam desde fora o conteúdo, mas, pelo contrário, são a determinação própria deste como a de algo espiritual. A música significa sensatez quanto mais perfeitamente ela de tal maneira se determinar - não desde quando seus momentos singulares expressam algo simbólico. Sua similitude com a linguagem cumpre-se quando ela se afasta da linguagem. 